\title{
Influences of ENSO on boreal summer intraseasonal oscillation over the western Pacific in decaying summer
}

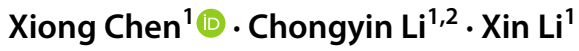

Received: 13 August 2019 / Accepted: 20 February 2020 / Published online: 2 March 2020

(c) The Author(s) 2020

\begin{abstract}
Characteristics of boreal summer intraseasonal oscillation (BSISO) over the western Pacific in ENSO decaying summer are revealed in this study. BSISO activity over the western Pacific is significantly weakened (strengthened) in El Niño (La Niña) decaying summer. Coherent and robust northward propagation (NP) of BSISO can be observed from the equator to the north of $25^{\circ} \mathrm{N}$ in La Niña decaying summer, while the intensity of BSISO NP is rapidly weakened to the north of $15^{\circ} \mathrm{N}$ in El Niño decaying summer. ENSO modulates BSISO activity by regulating circulation and moisture anomalies. Large-scale atmospheric circulation undergoes radical changes between El Niño and La Niña decaying summer. In El Niño (La Niña) decaying summer, anomalous anticyclonic (cyclonic) circulation and descending (ascending) motion are observed over the western Pacific, which provides an unfavorable (favorable) background state for the activity of BSISO. Low-level moistening north of BSISO convection center is crucial to its activity and NP, and the stronger low-level moistening in La Niña decaying summer induces the stronger NP. Differences in moisture variations between El Niño and La Niña decaying summer mainly stem from the meridional moisture advection, especially the meridional advection of intraseasonal moisture caused by lowfrequency background state meridional wind. The stronger air-sea interaction over $15^{\circ}-25^{\circ} \mathrm{N}$ in La Niña decaying summer could also promote the stronger NP of BSISO via surface heat fluxes exchanges. Zonal and meridional vertical wind shears can also influence the boundary convergence to the north of BSISO convection center and promote the NP of BSISO via vertical wind shear and vorticity advection mechanisms, but they are not the dominant reasons for the differences in the NP of BSISO between El Niño and La Niña decaying summer.
\end{abstract}

Keywords Boreal summer intraseasonal oscillation (BSISO) $\cdot$ El niño-southern oscillation (ENSO) · Northward propagation $(\mathrm{NP}) \cdot$ Moisture budget $\cdot$ Dynamic mechanism

\section{Introduction}

Tropical atmospheric intraseasonal oscillation (ISO) is a prominent component of tropical atmosphere variations and is dominated by the Madden-Julian Oscillation (MJO) near the equatorial regions (Madden and Julian 1971, 1972). In boreal summer, ISO activity over the western Pacific is mainly located to the north of the equator and shows

Xiong Chen

chenx_zc_mail@sina.com

1 College of Meteorology and Oceanography, National University of Defense Technology, Nanjing 211101, China

2 State Key Laboratory of Numerical Modeling for Atmospheric Sciences and Geophysical Fluid Dynamics (LASG), Institute of Atmospheric Physics, Chinese Academy of Sciences, Beijing 100029, China prominent northward propagation (NP) features (Jiang et al. 2004, 2018; Liu and Wang 2014; Liu et al. 2016). The NP of boreal summer ISO (BSISO) can modulate the onset, break and retreat of summer monsoon (Zhou and Murtugudde 2014; Wang et al. 2018a; Karmakar and Krishnamurti 2019) and has significant impacts on the weather and climate anomalies over East Asia (Zhang 2013). Thus, weather prediction in East Asia may benefit from the accurate prediction of BSISO, especially its NP.

Several mechanisms have been advanced to explain the NP of BSISO (Wang and Xie 1996; Xie and Wang 1996; Jiang et al. 2004; Bellon and Sobel 2008; Zheng and Huang 2019). Jiang et al. (2004) proposed the vertical wind shear mechanism for the NP of BSISO, which was further confirmed with numerical simulation studies (Drbohlav and Wang 2005; Yang et al. 2019). Under a background state flow with easterly vertical wind shear, the combination of 
vertical shear flow and meridional gradient of baroclinic divergence could lead to positive barotropic vorticity in the free atmosphere to the north of convection center. The positive barotropic vorticity will induce a barotropic divergence, which further leads to a convergence in the boundary layer and promotes BSISO northwards propagating. The easterly vertical wind shear could also promote the NP of BSISO via convective momentum transport process. Under a background state flow with easterly vertical wind shear, the effects of convective momentum transport can enhance the low-level troposphere convergence north of convection center by inducing a baroclinic secondary circulation and positive barotropic vorticity tendency (Kang et al. 2010; Liu et al. 2015). The activity and NP of BSISO are also related to the meridional vertical wind shear. The meridional advection of baroclinic vorticity induced by the mean flow with northerly vertical wind shear could induce barotropic vorticity in the free atmosphere north of the convection center, which in turn creates convergence in the boundary layer (Bellon and Sobel 2008). Zheng and Huang (2019) demonstrated that the meridional advection of barotropic vorticity by the mean barotropic southerly flows is the main reason for the NP of ISO over the South China Sea (SCS) during the premonsoon period. All above mechanisms highlight the importance of the asymmetric vorticity with respect to the convection center, while shallow convection plays a crucial role in conveying the asymmetric vorticity effect to inducing the NP of BSISO (Liu et al. 2018). The convergence in the boundary layer cannot develop into the deeper convection if the detrainment of shallow convection is turned off in a general circulation model (Liu et al. 2018).

Jiang et al. (2004) had also indicated the role of moistureconvection feedback mechanism in the NP of BSISO. BSISO is a coupled system of circulation and convection, thus lowlevel moistening to the north of BSISO convection center is critical for its activity and propagation (Hsu et al. 2004; Jiang et al. 2004; DeMott et al. 2013; Zheng and Huang 2019). Moisture convergence could lead to the generation of atmospheric instability and trigger deep convection, which will promote the NP of BSISO (Katsumata et al. 2013; Liu et al. 2015; Jiang et al. 2018). The combined effects of wind and moisture on intraseasonal and low-frequency (seasonal mean) timescales are the main contributors to the moistening anomalies north of convection center (Chou and Hsueh 2010; Jiang et al. 2004, 2018).

Besides the internal atmospheric processes, the effects of air-sea interaction in promoting the NP of BSISO have also been demonstrated by many studies (Kemball-Cook and Wang 2001; DeMott et al. 2013, 2015; Wang et al. 2018b; Gao et al. 2019). BSISO convection influences the sea surface temperature (SST) through regulating solar radiation, heat fluxes, and mixed-layer entrainment, but the feedback effects of SST anomalies (heating, moistening, and destabilizing the low-level atmosphere) also have significant impacts on the BSISO activity (Kemball-Cook and Wang 2001; Fu et al. 2003; Fu and Wang 2004; Wang et al. 2018b). Fu and Wang (2004) found that the BSISO activity and its relationship with the underlying SST are more realistic in a coupled model and the ISO is approximately $50 \%$ stronger in a coupled model than in the atmosphere-only model (Fu et al. 2003). Wang et al. (2009) had indicated that the effect of air-sea interaction is more important to the north of $12^{\circ} \mathrm{N}$, where the internal atmospheric dynamics alone are not sufficient for the NP of BSISO.

As the underlying surface of ISO activity, SST anomalies can modulate the initiation, propagation, intensity and interannual variations of ISO (Ajayamohan et al. 2008; Hsu and Xiao 2017; Wang et al. 2018c; Li and Mao 2019). In the developing stage of El Niño, ISO activity over the western Pacific is enhanced, while it is weakened under La Niña condition (Teng and Wang 2003; Lin and Li 2008; Chen et al. 2015; Wu and Song 2018). In El Niño (La Niña) developing summer, BSISO is dominated by a higher-frequency and shows prominent northwestward propagation, while the lower-frequency period is more significant in La Niña decaying summer, and BSISO is characterized by robust NP in La Niña phase (Liu et al. 2016). Compared with the developing summer, El Niño-Southern Oscillation (ENSO) has stronger influences on BSISO in decaying summer (Lin and Li 2008). ISO activity over the western Pacific is significantly weakened (enhanced) in $\mathrm{El}$ Niño (La Niña) decaying summer (Hendon et al. 2007; Lin and Li 2008; Chen et al. 2015). Lin and Li (2008) had explored the influences of ENSO on the NP of BSISO in decaying summer using wavenumber-frequency analysis, but the physical processes of these influences were not revealed. Therefore, more detailed research about the impacts of ENSO on BSISO in decaying summer and their mechanisms is needed.

In this paper, we will focus on whether ENSO influences the activity of BSISO and its NP over the western Pacific in decaying summer. Are the NP characteristics of BSISO disparate under the two different conditions? If so, what are the reasons and mechanisms for these differences? The remainder of this paper is organized as follows: the data and methods utilized in this study are briefly described in Sect. 2. The influences of ENSO on the activity and NP of BSISO over the western Pacific in decaying summer are explored in Sect. 3. Reasons and mechanisms for the ENSO influences are addressed in Sect. 4. Finally, conclusions and discussions are provided in Sect. 5.

\section{Data and methods}

The reanalysis datasets used in this paper mainly include (i) daily three-dimensional winds and specific humidity data with a horizontal resolution of $1.5^{\circ} \times 1.5^{\circ}$ from the 
ERA-Interim global atmospheric reanalysis datasets (Dee et al. 2011); (ii) daily outgoing longwave radiation (OLR) from the National Oceanic and Atmospheric Administration (NOAA) with a horizontal resolution of $2.5^{\circ} \times 2.5^{\circ}$ (Liebmann and Smith 1996); (iii) daily sea surface temperature (SST) data with a horizontal resolution of $0.25^{\circ} \times 0.25^{\circ}$ from the NOAA OISST V2 High Resolution Dataset (Reynolds et al. 2007), and monthly SST data with a horizontal resolution of $2.0^{\circ} \times 2.0^{\circ}$ from the NOAA Extended Reconstructed SST V5 (Huang et al. 2017); (iv) pentad precipitation data from the Climate Prediction Center (CPC) Merged Analysis of Precipitation (CMAP) on a $2.5^{\circ} \times 2.5^{\circ}$ horizontal grid (Xie and Arkin 1997), and for direct comparisons, the CMAP data were interpolated from their original pentad to the OLR daily following Zhang and Ling (2017); and (v) daily downward net heat flux, downward shortwave and upward longwave radiative fluxes, and upward sensible and latent heat fluxes from the Woods Hole Oceanographic Institution Objectively Analyzed Air-Sea Fluxes daily data at $1.0^{\circ} \times 1.0^{\circ}$ spatial resolution (Yu and Weller 2007). The period is from 1979 to 2017 for ERA-Interim atmospheric data, OLR, pentad precipitation, and monthly SST, and is from 1981 to 2017 for daily SST data, and is from 1985 to 2017 for sensible and latent heat fluxes, and is from 1985 to 2009 for net heat flux, shortwave and longwave radiative fluxes.

The anomaly of a given variable was defined as its departure from its climatological mean of each day (month), and the linear trend was also removed. Both the quasi-biweekly and intraseasonal oscillations are prominent over the western Pacific in boreal summer (Lee et al. 2013; Liu et al. 2016), but only the intraseasonal oscillation is investigated in this study. The ISO signal was obtained using 30-90 days Lanczos bandpass filter (Duchon 1979; Chen et al. 2016). BSISO activity intensity is described by the BSISO amplitude, which is defined as the standard deviation of daily ISO zonal wind at $850 \mathrm{hPa}$ and OLR with a 3-month moving window (Chen et al. 2016). ENSO decaying summer (May-September) is defined as the Niño 3.4 index in the previous winter (November-March) exceeding 0.8 standard deviations, and 8 El Niño decaying summers (1983, 1987, 1992, 1995, 1998, 2003, 2010, 2016) and 8 La Niña decaying summers (1985, 1989, 1996, 1999, 2000, 2008, 2011, 2012) are identified.

\section{Characteristics of BSISO in ENSO decaying summer}

\subsection{Characteristics of BSISO intensity}

BSISO activity over the western Pacific is vigorous and shows remarkable interannual variations (Teng and Wang 2003; Liu et al. 2016). Figure 1 shows the differences of
BSISO amplitude between El Niño and La Niña decaying summers. BSISO amplitude of zonal wind at $850 \mathrm{hPa}$ is significantly weakened (strengthened) over the SCS and western Pacific from $5^{\circ} \mathrm{S}$ to $20^{\circ} \mathrm{N}$ in El Niño (La Niña) decaying summer, especially over the SCS and Philippine areas (Fig. 1a). BSISO amplitude of OLR is also weakened (strengthened) over these regions in El Niño (La Niña) decaying summer. But significant differences of BSISO OLR activity between El Niño and La Niña decaying summers are located over the western Pacific east of the Philippine, and the differences over the SCS are not significant (Fig. 1b). The inconsistency between zonal wind and OLR amplitude anomalies may stem from the phase difference between circulation and convection because the convection center is inconsistent with the maximum center of zonal wind.
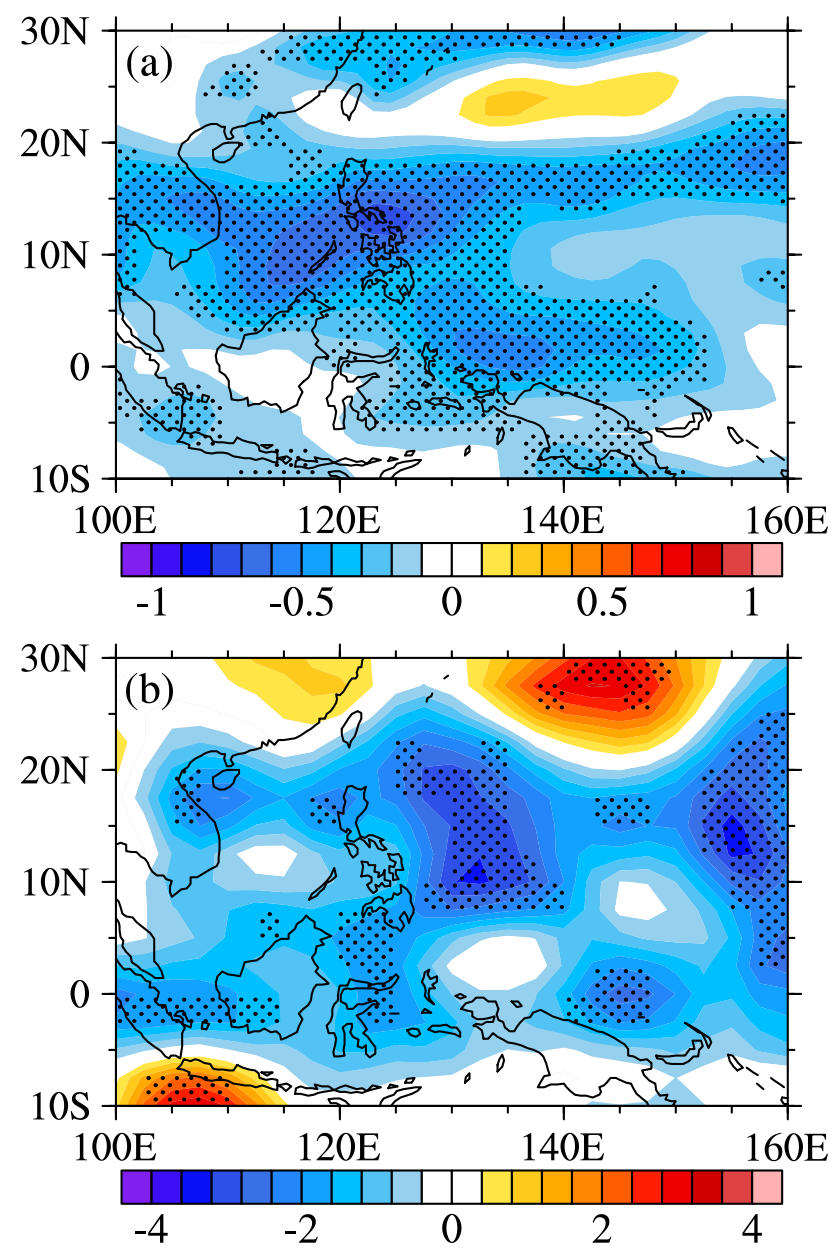

Fig. 1 Composite differences of the BSISO amplitude of a zonal wind at $850 \mathrm{hPa}\left(\mathrm{m} \mathrm{s}^{-1}\right)$ and $\mathbf{b}$ OLR $\left(\mathrm{W} \mathrm{m}^{-2}\right)$ between El Niño and La Niña decaying summer (El Niño minus La Niña). Results exceeding $90 \%$ significance level are stippled 


\subsection{Northward propagation of BSISO}

To analyze the NP features of BSISO, wavenumber-frequency analyses are carried out in the meridional direction following Teng and Wang (2003). The wavenumber-frequency spectra were calculated at each longitude in every summer and then averaged in El Niño and La Niña decaying summer. The spectra of northward propagation averaged at wavenumbers $1-2$ for zonal wind at $850 \mathrm{hPa}$, OLR and precipitation are shown in Fig. 2. Remarkable NP spectra can be observed over $70^{\circ}-90^{\circ} \mathrm{E}, 105^{\circ}-120^{\circ} \mathrm{E}$, and $120^{\circ}-140^{\circ}$ $\mathrm{E}$, and the dominant period is approximately 30-90 days. The NP spectra over these three regions are much weaker in El Niño decaying summer than that in La Niña decaying summer, indicating that the NP of BSISO is stronger and more prominent in La Niña decaying summer.

To illustrate the ENSO influences on the NP of BSISO clearly, composite analyses are carried out for the NP BSISO cases over the western Pacific. NP BSISO cases are selected as follows: (i) BSISO OLR averaged over $0^{\circ}-10^{\circ} \mathrm{N}$, $120^{\circ}-140^{\circ} \mathrm{E}$ is taken as BSISO index; (ii) a NP BSISO case is selected if the BSISO index is lower than one standard deviation for 5 consecutive days and the ISO OLR averaged over $120^{\circ}-140^{\circ} \mathrm{E}$ shows continuously northwards propagating from the equator to north of $25^{\circ} \mathrm{N}$ (continuously northward propagation means that the negative ISO OLR (zero contour of ISO OLR) can propagate from the equator to north of $25^{\circ} \mathrm{N}$ without any interruption or gap between days). The day with the minimum BSISO index is labeled as day 0 for each case, which is listed in Table 1.

$\mathrm{NP}$ of BSISO in terms of zonal wind at $850 \mathrm{hPa}$, OLR and precipitation in El Niño and La Niña decaying summer is composited in Fig. 3. BSISO shows noticeable NP in both El Niño and La Niña decaying summer, but there are also prominent differences. The intensity of BSISO activity near the equator $\left(0^{\circ}-10^{\circ} \mathrm{N}\right)$ is comparable between El Niño and La Niña decaying summer, but it is rapidly weakened to the north of $15^{\circ} \mathrm{N}$ in El Niño decaying summer. BSISO OLR and precipitation are enhanced again near $15^{\circ} \mathrm{N}$ and quickly weakened to the north of $25^{\circ} \mathrm{N}$ in La Niña decaying
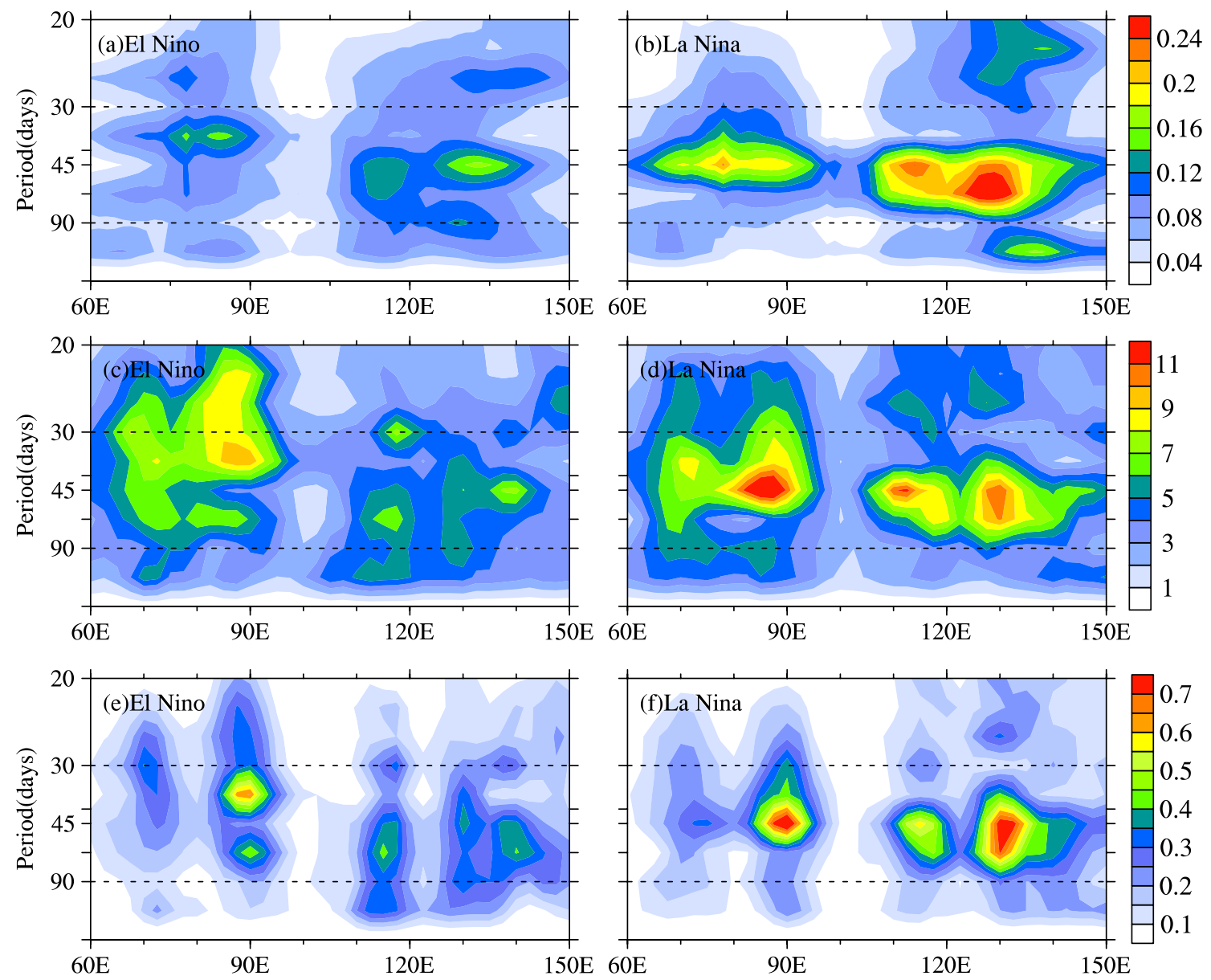

Fig. 2 Composite wavenumber-frequency spectra of northward propagation averaged at wavenumbers 1-2 in (left column) El Niño and (right column) La Niña decaying summer (from May to October). a,

b Zonal wind at $850 \mathrm{hPa}$ over $10.5^{\circ} \mathrm{S}-30^{\circ} \mathrm{N}, \mathbf{c}, \mathbf{d}$ are OLR over $7.5^{\circ}$ $\mathrm{S}-30^{\circ} \mathrm{N}$, and e, f are precipitation over $7.5^{\circ} \mathrm{S}-30^{\circ} \mathrm{N}$ 
Table 1 Day 0 of the NP BSISO cases used to composite in El Niño and La Niña decaying summer

\begin{tabular}{lll}
\hline No. & El Niño decaying summer & $\begin{array}{l}\text { La Niña } \\
\text { decaying } \\
\text { summer }\end{array}$ \\
\hline 1 & 1987.06 .03 & 1985.07 .31 \\
2 & 1987.07 .07 & 1989.08 .23 \\
3 & 1992.06 .15 & 1996.07 .17 \\
4 & 1995.07 .03 & 1996.08 .31 \\
5 & 1995.08 .31 & 1999.08 .24 \\
6 & 2003.05 .13 & 2000.07 .05 \\
7 & 2003.07 .17 & 2000.08 .18 \\
8 & 2003.09 .05 & 2008.05 .03 \\
9 & 2016.05 .21 & 2008.09 .13 \\
10 & 2016.06 .27 & 2012.05 .28 \\
11 & 2016.08 .02 & 2012.07 .22 \\
\hline
\end{tabular}
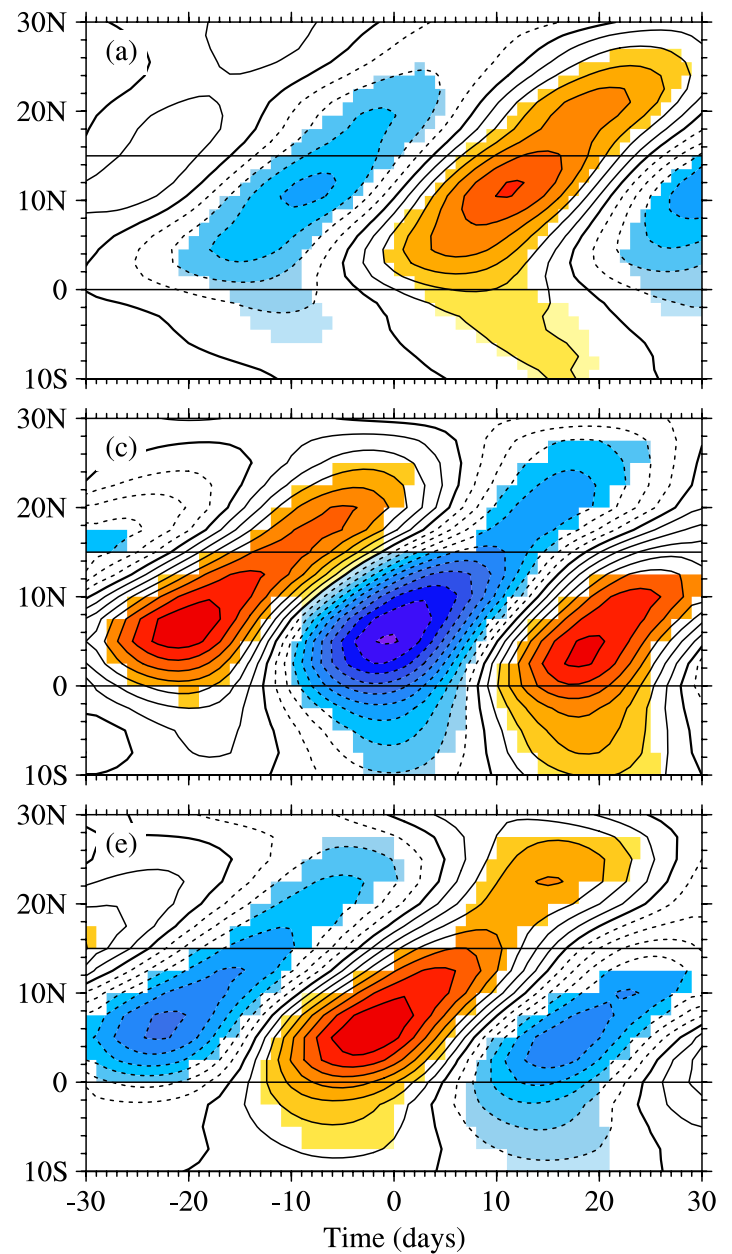

Fig. 3 Hovmöller diagram of composite ISO $\mathbf{a}, \mathbf{b}$ zonal wind at $850 \mathrm{hPa}\left(\mathrm{m} \mathrm{s}^{-1}\right)$, c, d OLR $\left(\mathrm{W} \mathrm{m} \mathrm{m}^{-2}\right)$, and e, f precipitation $(\mathrm{mm}$ day $^{-1}$ ) in (left column) El Niño and (right column) La Niña decaying summer (Fig. 3d, f). The robust and coherent NP of BSISO is very prominent from the equator to the north of $25^{\circ} \mathrm{N}$ in La Niña decaying summer, but the vigorous NP is mainly located south of $15^{\circ} \mathrm{N}$ in El Niño decaying summer. In order to investigate the robustness of these results, we have conducted the following three tests: (i) compositing the meridional propagation based on the BSISO case that not considers its continuously NP (only the BSISO index lower than one standard deviation for 5 consecutive days is considered); (ii) BSISO index is defined based on different regions (e.g. $5^{\circ}-15^{\circ} \mathrm{N}, 10^{\circ}-20^{\circ} \mathrm{N}$ ); (iii) analyzing the meridional propagation of BSISO using regression analysis following Chen et al. (2016). Results in these three tests show similar features as in Fig. 3, which indicates that the results are stable and not vary with the sample sizes and methods.

Above analyses demonstrated that ENSO has significant influences on the intensity and NP of BSISO over the western Pacific in decaying summer, and we will attempt to
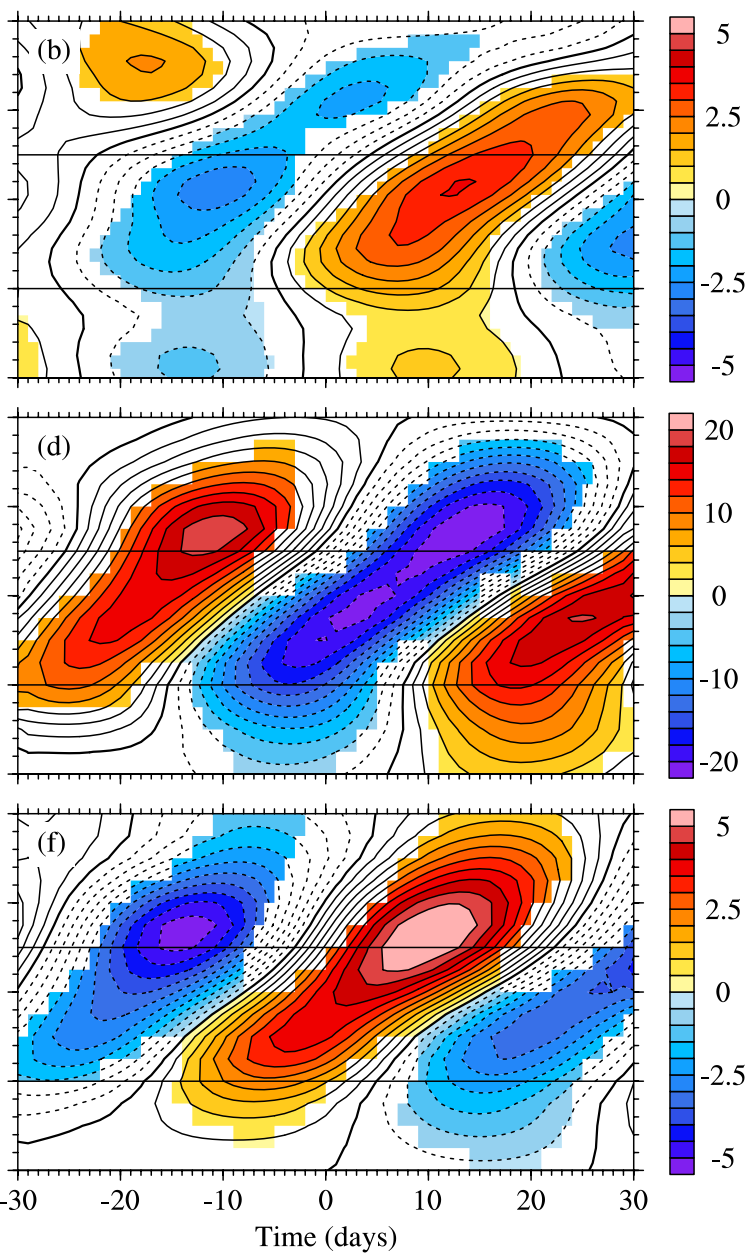

summer. The horizontal axis is time (days), and the vertical axis is latitude. Negative is dashed, and the zero contours are bolded. Results exceeding $90 \%$ significance level are colored 
elucidate the reasons for these influences of ENSO in the following section.

\section{Causes of the ENSO influences on BSISO}

\subsection{Large-scale atmospheric circulation}

Large-scale circulation anomalies induced by ENSO over the western Pacific play an important role in connecting ENSO events and its climatic impacts, which can persist until the following summer (Wang et al. 2000; Xie et al. 2009). Composite anomalous circulation and its divergence at $850 \mathrm{hPa}$ in El Niño and La Niña decaying summer are shown in Fig. 4. As indicated by previous researches, the circulation anomaly between the two phases of ENSO shows prominent antisymmetric features (Wu et al. 2010; Chen et al. 2019). In El Niño decaying summer, an abnormal anticyclonic circulation extending from the Indo-China Peninsula to the central Pacific can be observed, which leads to significantly anomalous divergence over the western Pacific (Fig. 4a). In La Niña decaying summer, an anomalous cyclonic circulation is observed over the western Pacific (Fig. 4b), but its intensity is weaker, and its range is also smaller than the anticyclonic circulation under El Niño condition. The anomalous cyclonic circulation is mainly over the area from 100 to $140^{\circ}$ $\mathrm{E}$, which induces anomalous convergence over there.

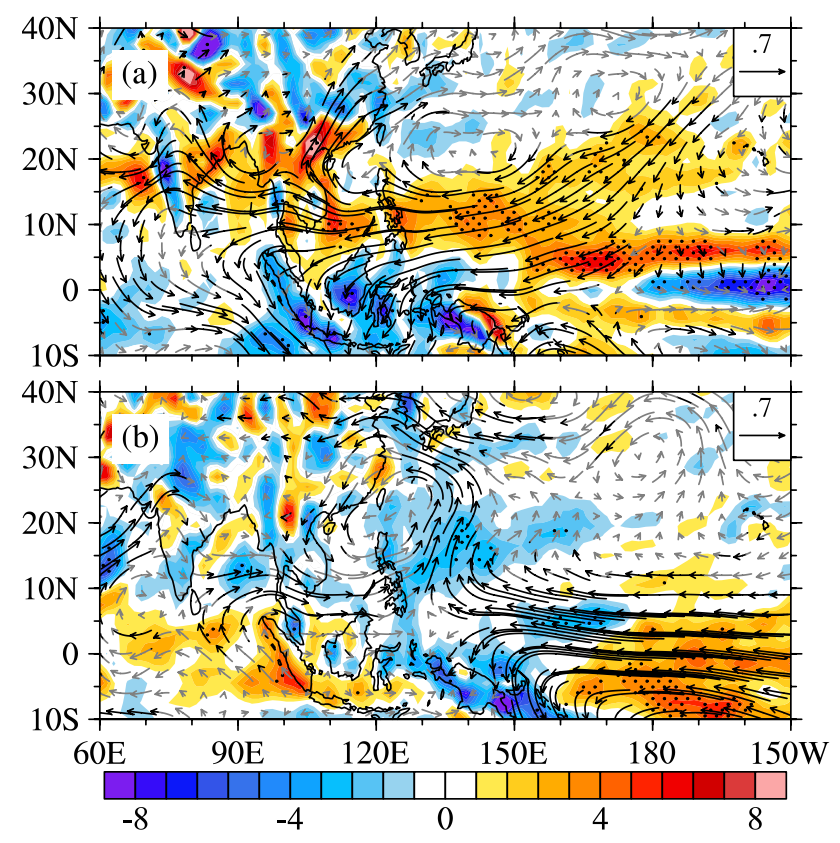

Fig. 4 Composite anomalous horizontal wind at $850 \mathrm{hPa}$ (vectors, $\mathrm{m} \mathrm{s}^{-1}$ ) and its divergence (colors, $10^{-7} \mathrm{~s}^{-1}$ ) in a El Niño and b La Niña decaying summer. Results exceeding $90 \%$ confidence level are stippled for divergence and marked with black for vectors
Anomalous circulation will lead to moisture transport and divergence anomalies. Composite anomalous moisture flux integrated from 1000 to $300 \mathrm{hPa}$ in El Niño decaying summer is shown in Fig. 5a. There is strong moisture transport from the central Pacific to the Indian Ocean. Significant moisture divergence occurs over the western Pacific between $5^{\circ}-20^{\circ} \mathrm{N}$, which is unfavorable to the ascending motion and convection activity. Therefore, northern parts of SCS and the western Pacific are dominated by anomalous descending motion, and convection is also suppressed there (Fig. 6a). However, in La Niña decaying summer, anomalous circulation leads to significant moisture convergence over the western Pacific (Fig. 5b), and the ascending motion is enhanced over the western Pacific west of $150^{\circ} \mathrm{E}$ (Fig. 6b). Consequently, convection over the western Pacific is also strengthened (Fig. 6b). The background large-scale atmospheric circulation and moisture change significantly in ENSO decaying summer, which is unfavorable (favorable) to the BSISO activity over the western Pacific in El Niño (La Niña) decaying summer.

\subsection{Dynamic mechanisms}

Asymmetry of atmospheric circulation with respect to the BSISO convection center is essential to its NP, and the strongest positive vorticity and convergence is just over the north of BSISO convection center (Jiang et al. 2004; Ajayamohan et al. 2008; Zheng and Huang 2019). Figure 7 shows the composite ISO OLR, horizontal relative vorticity at

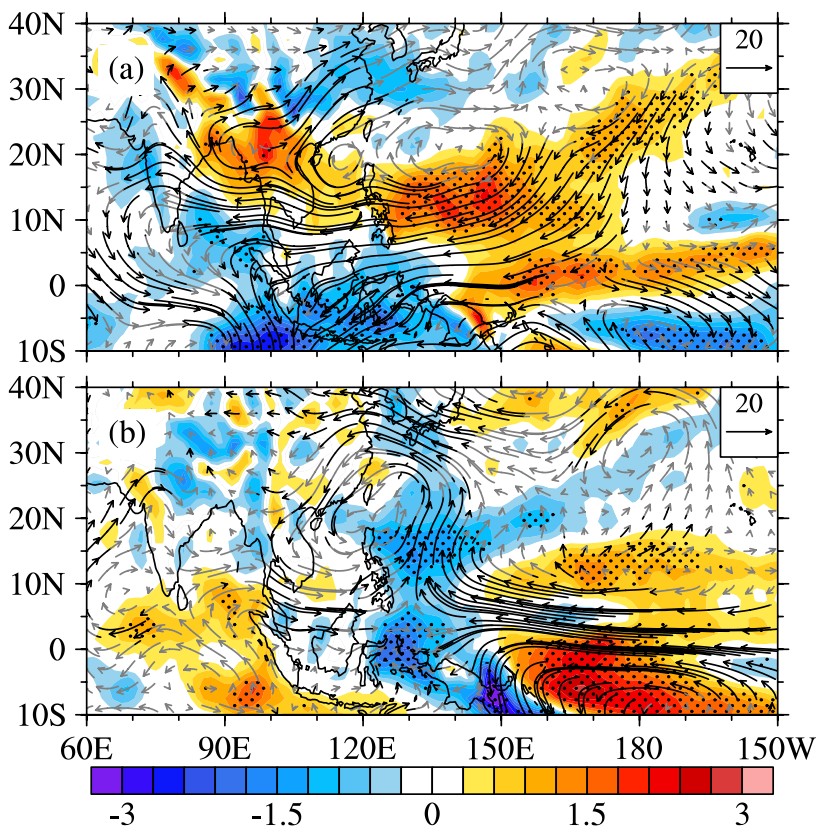

Fig. 5 As in Fig. 4, but for the moisture flux $\left(\mathrm{g} \mathrm{m}^{-1} \mathrm{~s}^{-1}\right)$ integrated from 1000 to $300 \mathrm{hPa}$ and its divergence $\left(10^{-4} \mathrm{~g} \mathrm{~m}^{-2} \mathrm{~s}^{-1}\right)$ 

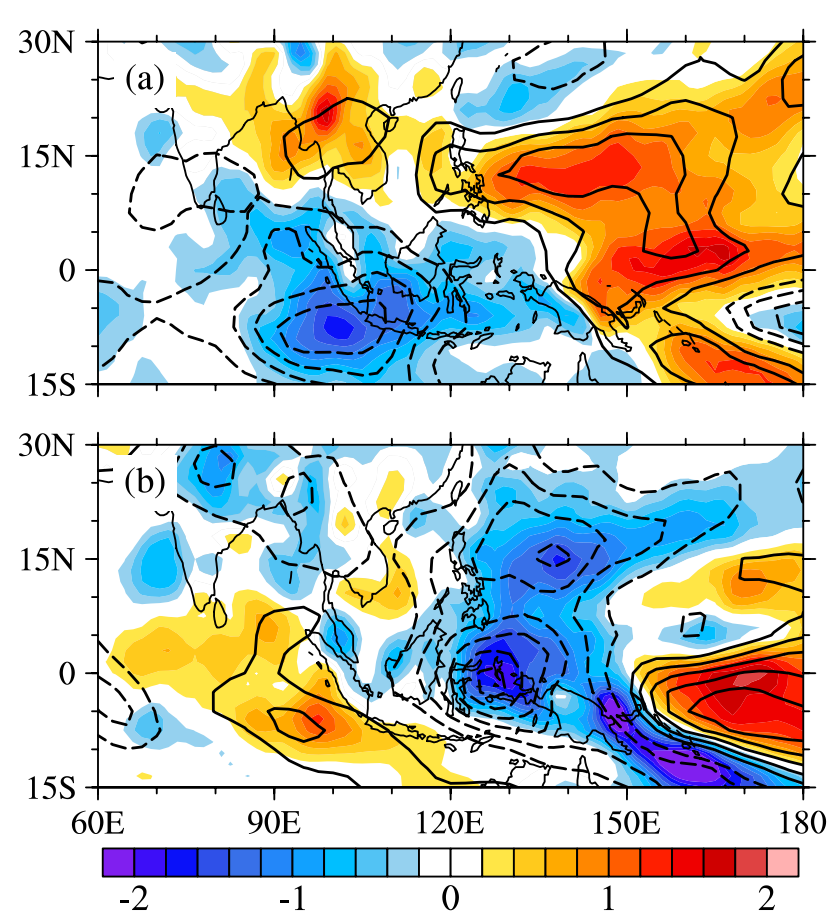

Fig. 6 Composite anomalous OLR (contours, negative is dashed, the interval is $2 \mathrm{~W} \mathrm{~m}^{-2}$, and the zero contours are omitted) and vertical velocity at $500 \mathrm{hPa}$ (colors, $10^{-2} \mathrm{~Pa} \mathrm{~s}^{-1}$ ) in a El Niño and b La Niña decaying summer

$850 \mathrm{hPa}$ and divergence at $925 \mathrm{hPa}$ averaged over $120^{\circ}-140^{\circ}$ $\mathrm{E}$ in El Niño and La Niña decaying summer at day 0. Convection center (presented by the minimum of ISO OLR) is near $5^{\circ} \mathrm{N}$, and its intensity is nearly the same between $\mathrm{El}$ Niño and La Niña decaying summer. Positive vorticity and convergence are mainly over the north of convection center, and their maximums are near $10^{\circ} \mathrm{N}$. Positive vorticity and convergence can reach $18^{\circ} \mathrm{N}$, and the boundary of positive vorticity is slightly north than the convergence. The intensity of vorticity and convergence north of convection center is stronger in La Niña decaying summer than that in El Niño decaying summer, which may be a reason for the stronger BSISO activity in La Niña decaying summer.

The effects of vertical wind shear and vorticity advection mechanisms are the dynamical processes that lead to these asymmetries in vorticity and divergence (Jiang et al. 2004; Bellon and Sobel 2008). Composite zonal vertical wind shear over the western Pacific in El Niño and La Niña decaying summer is shown in Fig. 8a. Easterly vertical wind shear is mainly to the south of $20^{\circ} \mathrm{N}$ in ENSO decaying summer, but its intensity is stronger under La Niña condition. The easterly vertical wind shear could lead to a positive barotropic vorticity in the free atmosphere to the north of BSISO convection center via vertical wind shear mechanism, which will then induce a convergence in the atmospheric boundary layer (Jiang et al. 2004). Moreover,

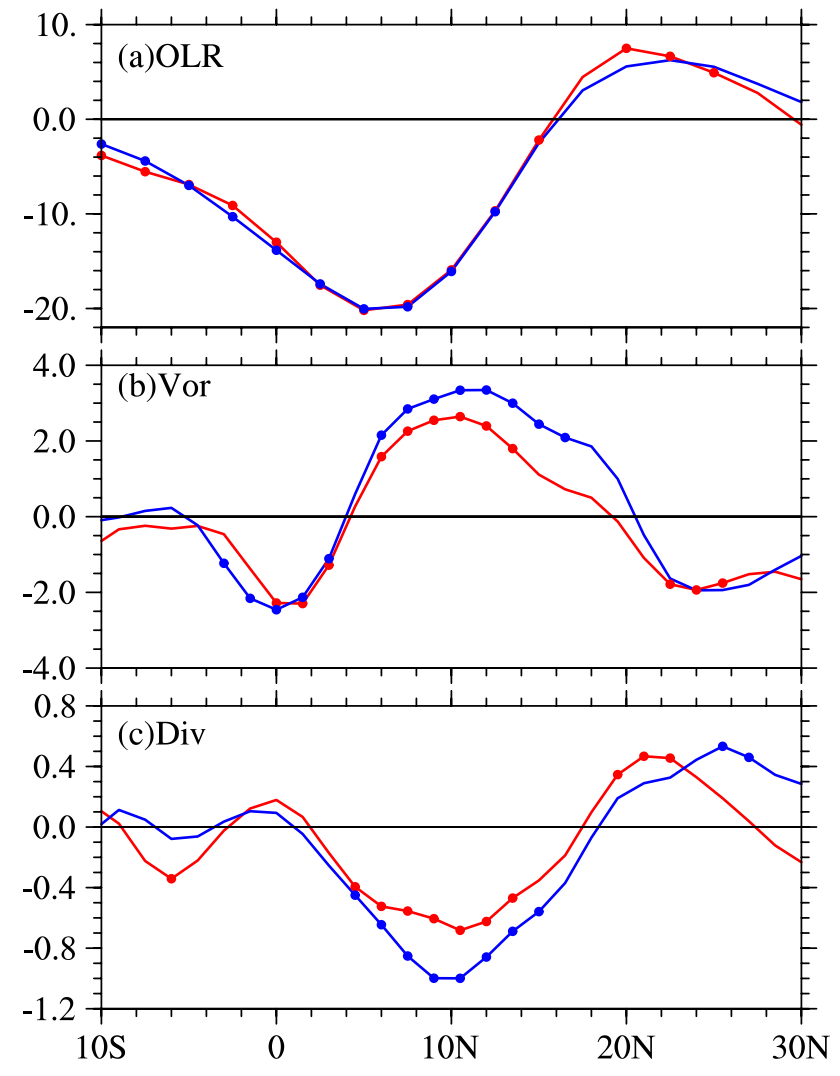

Fig. 7 Composite ISO a OLR $\left(\mathrm{W} \mathrm{m}^{-2}\right)$, b relative vorticity at $850 \mathrm{hPa}\left(10^{-6} \mathrm{~s}^{-1}\right)$, and c divergence at $925 \mathrm{hPa}\left(10^{-6} \mathrm{~s}^{-1}\right)$ at day 0 in (red lines) El Niño and (blue lines) La Niña decaying summer. Results exceeding $90 \%$ confidence level are dotted

the easterly vertical wind shear can also lead to the lowlevel convergence to the north of BSISO convection via convective momentum transport and promote the NP of BSISO (Kang et al. 2010; Liu et al. 2015). The stronger easterly vertical wind shear could lead to the stronger activity and NP of BSISO in La Niña decaying summer, but its effects are mainly confined to the south of $20^{\circ} \mathrm{N}$.

Meridional vertical wind shear plays a crucial role in the vorticity advection mechanism, and composite meridional vertical wind shear over the western Pacific in El Niño and La Niña decaying summer is shown in Fig. 8b. Northerly vertical wind shear is over the whole tropical western Pacific, which could promote the NP of BSISO by inducing a boundary layer convergence (Bellon and Sobel 2008). However, the northerly vertical wind shear is stronger (weaker) north (south) of $15^{\circ} \mathrm{N}$ in the El Niño decaying summer than in La Niña decaying summer, which means that the vorticity advection mechanism could lead to a stronger (weaker) convergence in the boundary layer north (south) of $15^{\circ} \mathrm{N}$ in El Niño decaying summer. Thus, the vorticity advection mechanism could account for the $\mathrm{NP}$ of BSISO, but it is not responsible for the differences 

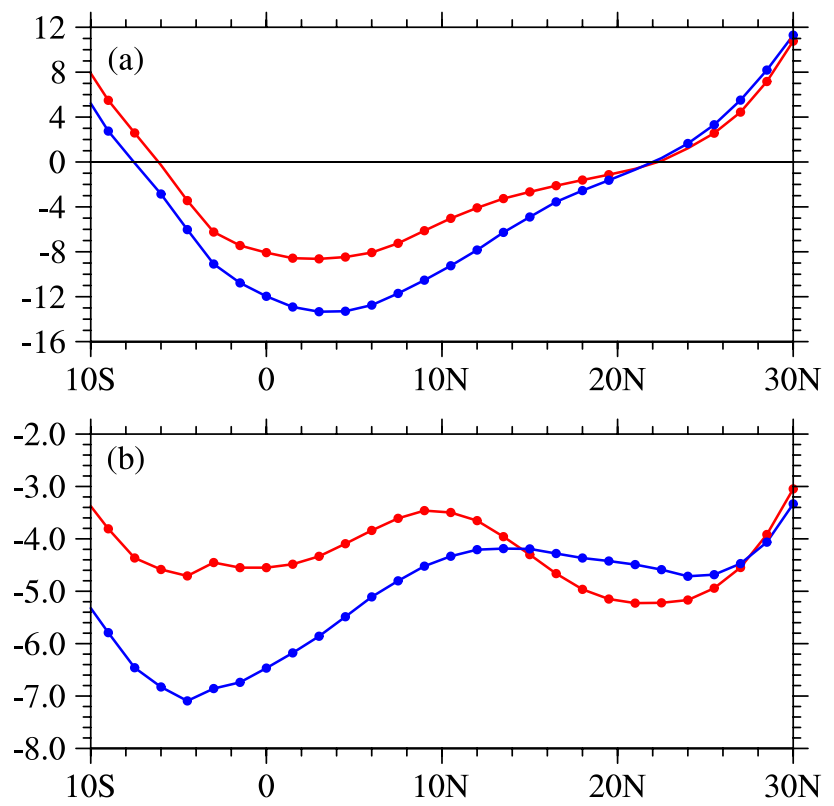

Fig. 8 Composite vertical wind shears of a zonal wind $\left(u_{200}-u_{850}\right)$ and $\mathbf{b}$ meridional wind $\left(v_{200}-v_{850}\right)$ averaged over $120^{\circ}-140^{\circ} \mathrm{E}$ in (red lines) El Niño and (blue lines) La Niña decaying summer. Results exceeding $90 \%$ confidence level are dotted. Unit: $\mathrm{m} \mathrm{s}^{-1}$

in BSISO NP between the El Niño and La Niña decaying summer.

\subsection{Moisture budget diagnosis}

Low-level moistening north of the BSISO convection center provides pre-conditions for its NP (Chou and Hsueh 2010; Jiang et al. 2004, 2018; Liu et al. 2015). Composite ISO OLR and specific humidity averaged between 1000 and $850 \mathrm{hPa}$ in El Niño and La Niña decaying summers are shown in Fig. 9. Positive specific humidity variations are leading the convection several days and stronger under La Niña condition. In El Niño decaying summer, specific humidity shows a noticeable NP south of $20^{\circ} \mathrm{N}$, which provides favorable conditions for the BSISO activity. However, specific humidity shows a prominent southward propagation north of $20^{\circ} \mathrm{N}$ (Fig. 9a), which is inconsistent with the convection activity and may be unfavorable to the NP of BSISO. In La Niña decaying summer (Fig. 9b), specific humidity is characterized by a prominent NP from $10^{\circ} \mathrm{S}$ to $30^{\circ} \mathrm{N}$ and enhanced to the north of $15^{\circ} \mathrm{N}$, which may explain the stronger BSISO activity and NP over this region.

To investigate the physical processes that contributes to the differences in the moistening, moisture budget is diagnosed using the moisture budget equation at the pressure level as follows (Chen et al. 2016):
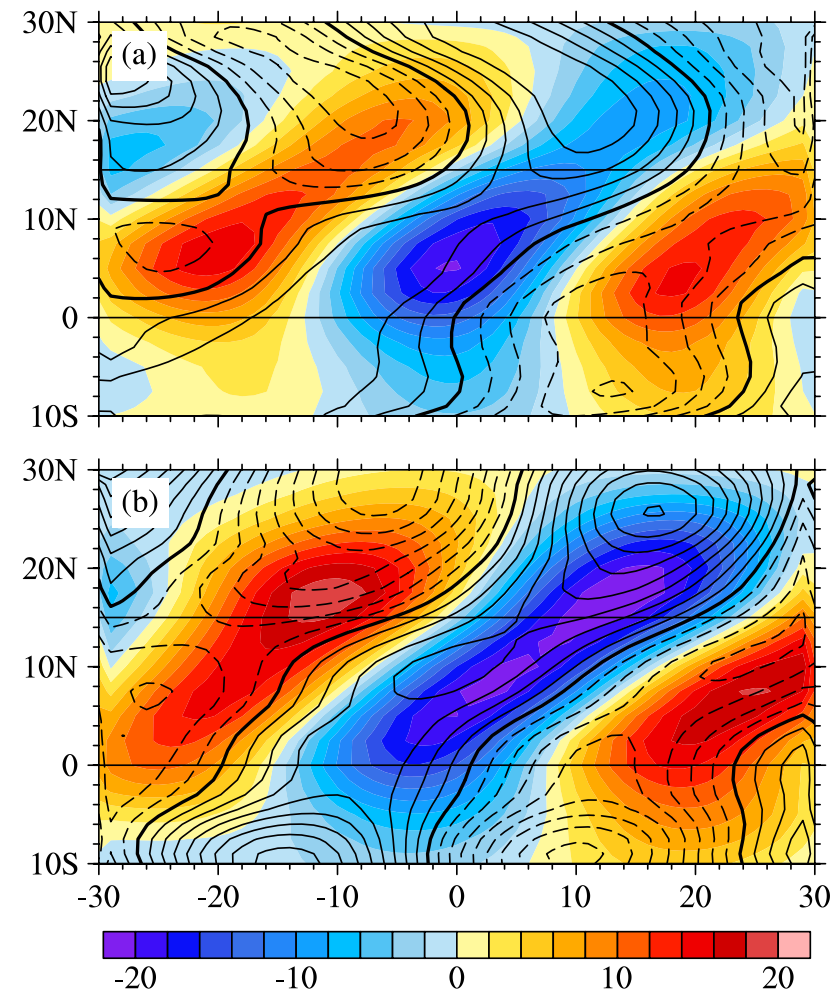

Fig. 9 Hovmöller diagram of composite ISO OLR $\left(\mathrm{W} \mathrm{m}^{-2}\right)$ and specific humidity averaged over $120^{\circ}-140^{\circ} \mathrm{E}, 1000-850 \mathrm{hPa}$ (contours, negative is dashed, the interval is $0.6 \mathrm{~g} \mathrm{~kg}^{-1}$, and the zero contours are bolded) in a El Niño and $\mathbf{b}$ La Niña decaying summer. The horizontal axis is time (days), and the vertical axis is latitude

$\frac{\partial q}{\partial t}=-u \frac{\partial q}{\partial x}-v \frac{\partial q}{\partial y}-\omega \frac{\partial q}{\partial p}-\frac{Q_{2}}{L}$

where $q, u, v, \omega, Q_{2}$, and $L$ denote the specific humidity, zonal, meridional, and vertical velocity, atmospheric apparent moisture sinks and latent heat of condensation, respectively. Figure 10 shows the individual terms in Eq. (1) averaged over the period when the moisture tendency shows noticeably different between El Niño and La Niña decaying summer. The moistening over $10^{\circ}-20^{\circ} \mathrm{N}$ is dominated by meridional advection of moisture, and the zonal and vertical advection of moisture hamper the moistening (Fig. 10a, b). The atmospheric apparent moisture sinks also contribute to the moistening over $15^{\circ}-20^{\circ} \mathrm{N}$, but its effects are mainly offset by the vertical advection of moisture. The moistening over $20^{\circ}-25^{\circ} \mathrm{N}$ is mainly contributed by vertical advection of moisture, which is stronger under El Niño condition (Fig. 10c). However, the negative effects of meridional moisture advection over $20^{\circ}-25^{\circ} \mathrm{N}$ are also strong under El Niño condition, which leads to drying north of convection center. Therefore, the net effects of meridional and vertical advection of moisture induce a weaker moisture tendency under El Niño condition (Fig. 10c). 

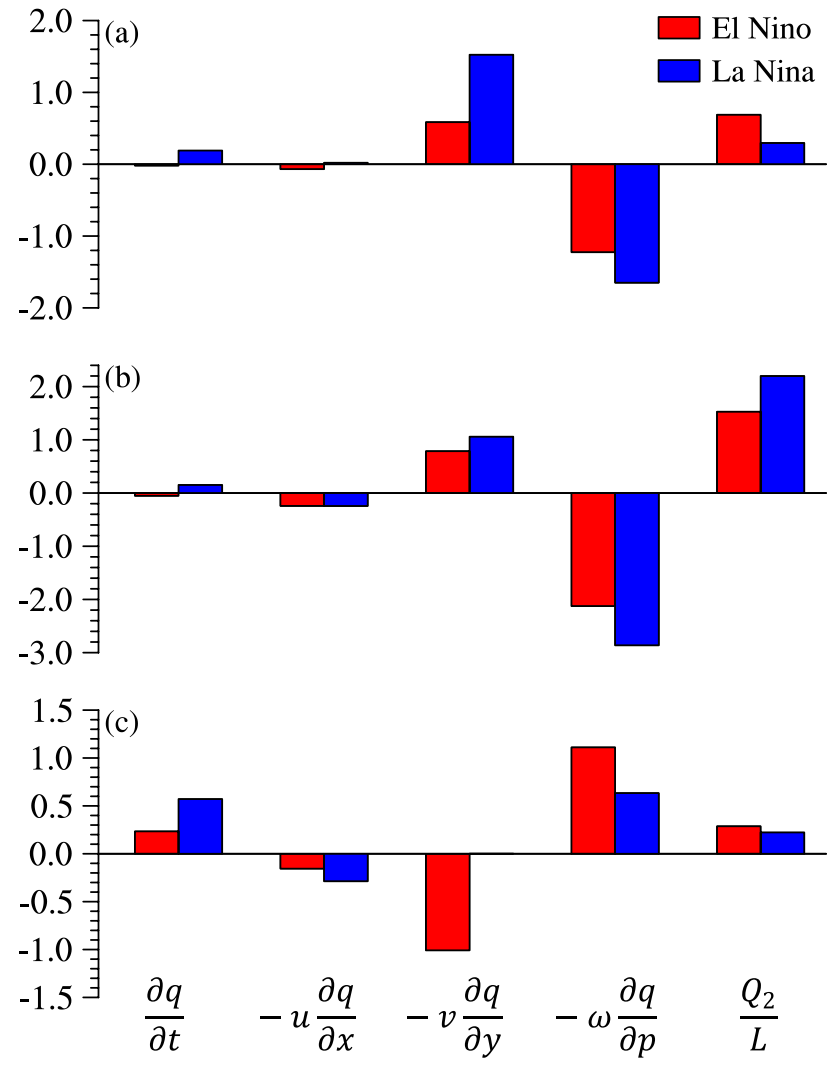

Fig. 10 Composites of each term in Eq. (1) averaged over a $10^{\circ}-15^{\circ}$ $\mathrm{N}, 120^{\circ}-140^{\circ} \mathrm{E}, 1000-850 \mathrm{hPa}$ from day -16 to -10 , b $15^{\circ}-20^{\circ}$ $\mathrm{N}, 120^{\circ}-140^{\circ} \mathrm{E}, 1000-850 \mathrm{hPa}$ from day -12 to -6 , and $\mathbf{c} 20^{\circ}-25^{\circ}$ $\mathrm{N}, 120^{\circ}-140^{\circ} \mathrm{E}, 1000-850 \mathrm{hPa}$ from day $4-10$ in (red) El Niño and (blue) La Niña decaying summer, unit: $10^{-9} \mathrm{~kg} \mathrm{~kg}^{-1} \mathrm{~s}^{-1}$

A variable can be further decomposed into three components according to the timescale, the high-frequency (<30 days), the ISO (30-90 day), and the low-frequency background state (LFBS, > 90 days) following Chen et al. (2016):

$A=A^{*}+A^{\prime}+\bar{A}$

where the asterisk, prime, and overbar denote the high-frequency, ISO, and LFBS components, respectively. Therefore, the meridional and vertical moisture advection can be written as:

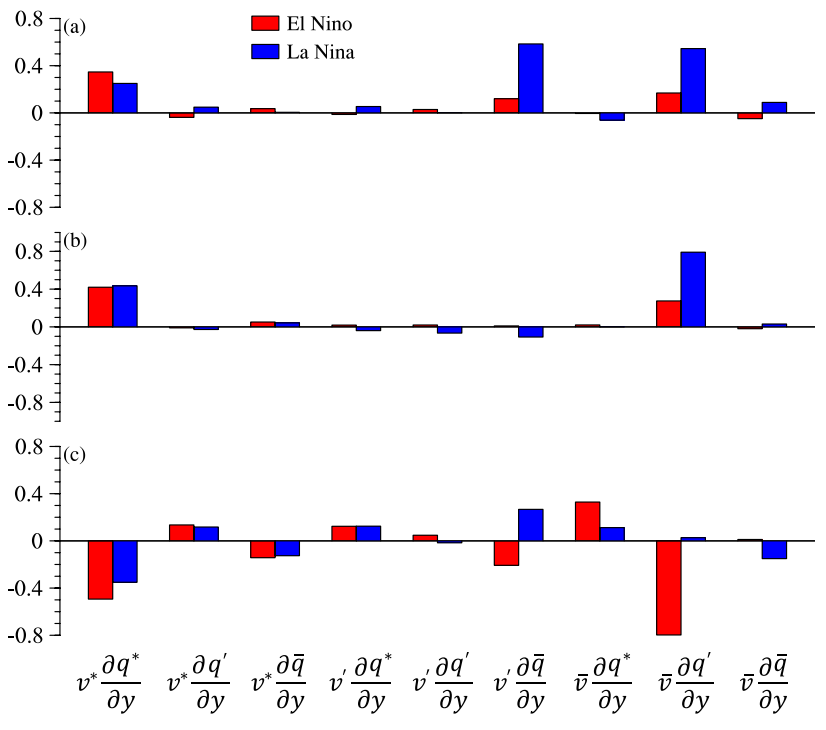

Fig. 11 As in Fig. 10, but for each term on the right side of Eq. (3)

Each term on the right side of Eq. (3) averaged over three different regions are shown in Fig. 11. Meridional advection of moisture over $10^{\circ}-15^{\circ} \mathrm{N}$ mainly stems from the advection of LFBS moisture caused by ISO meridional wind $\left(v^{\prime} \frac{\partial \bar{q}}{\partial y}\right)$ and the advection of ISO moisture caused by the LFBS meridional wind $\left(\bar{v} \frac{\partial q^{\prime}}{\partial y}\right)$, and these two terms are much stronger in La Niña decaying summer (Fig. 11a). Stronger meridional advection of moisture over $15^{\circ}-20^{\circ} \mathrm{N}$ in La Niña decaying summer mainly results from the advection of ISO moisture caused by LFBS meridional flows $\left(\bar{v} \frac{\partial q^{\prime}}{\partial y}\right)$ (Fig. 11b). The high-frequency variation $\left(v^{*} \frac{\partial q^{*}}{\partial y}\right)$ also contributes to the moistening over $10^{\circ}-20^{\circ} \mathrm{N}$, although its effects are relatively weaker. Terms $\bar{v} \frac{\partial q^{\prime}}{\partial y}$ and $v^{*} \frac{\partial q^{*}}{\partial y}$ are the main contributors to the stronger negative meridional moisture advection over $20^{\circ}-25^{\circ} \mathrm{N}$ in El Niño decaying summer. The effects of the term $v^{\prime} \frac{\partial \bar{q}}{\partial y}$ are opposite between El Niño and La Niña conditions and contribute the moisture divergence (convergence) in El Niño (La Niña) condition (Fig. 11c). We also analyze the vertical advection over $20^{\circ}-25^{\circ} \mathrm{N}$ based on Eq. (4). The positive vertical advection of moisture over $20^{\circ}-25^{\circ} \mathrm{N}$

$v \frac{\partial q}{\partial y}=v^{*} \frac{\partial q^{*}}{\partial y}+v^{*} \frac{\partial q^{\prime}}{\partial y}+v^{*} \frac{\partial \bar{q}}{\partial y}+v^{\prime} \frac{\partial q^{*}}{\partial y}+v^{\prime} \frac{\partial q^{\prime}}{\partial y}+v^{\prime} \frac{\partial \bar{q}}{\partial y}+\bar{v} \frac{\partial q^{*}}{\partial y}+\bar{v} \frac{\partial q^{\prime}}{\partial y}+\bar{v} \frac{\partial \bar{q}}{\partial y}$,

$\omega \frac{\partial q}{\partial p}=\omega^{*} \frac{\partial q^{*}}{\partial p}+\omega^{*} \frac{\partial q^{\prime}}{\partial p}+\omega^{*} \frac{\partial \bar{q}}{\partial p}+\omega^{\prime} \frac{\partial q^{*}}{\partial p}+\omega^{\prime} \frac{\partial q^{\prime}}{\partial p}+\omega^{\prime} \frac{\partial \bar{q}}{\partial p}+\bar{\omega} \frac{\partial q^{*}}{\partial p}+\bar{\omega} \frac{\partial q^{\prime}}{\partial p}+\bar{\omega} \frac{\partial \bar{q}}{\partial p}$. 


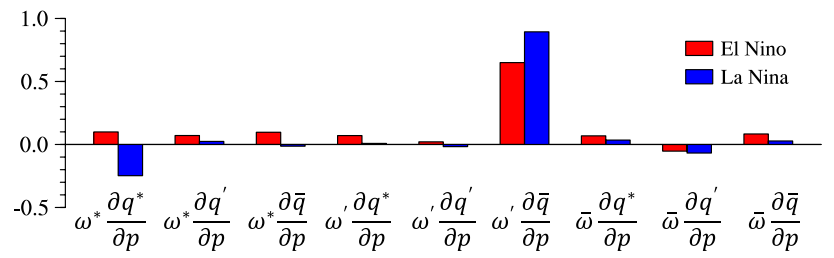

Fig. 12 Composite each term on the right side of Eq. (4) averaged over $20^{\circ}-25^{\circ} \mathrm{N}, 120^{\circ}-140^{\circ} \mathrm{E}, 1000-850 \mathrm{hPa}$ from day $4-10$ in (red) El Niño and (blue) La Niña decaying summer, unit: $10^{-9} \mathrm{~kg} \mathrm{~kg}^{-1} \mathrm{~s}^{-1}$

mainly stems from the advection of LFBS moisture by ISO vertical motion, which is stronger in La Niña condition (Fig. 12). However, the other terms on the right side of Eq. (4) also enhance the vertical moisture advection under El Niño condition, while the high-frequency variation induces moisture divergence in La Niña condition. Therefore, the vertical advection of moisture is stronger in El Niño decaying summer (Fig. 10c).

\subsection{Effects of air-sea interaction}

Air-sea interaction has been suggested to play an important role in the NP of BSISO (Fu et al. 2003; Fu and Wang 2004; Wang et al. 2018b). Figure 13 displays the time-latitude
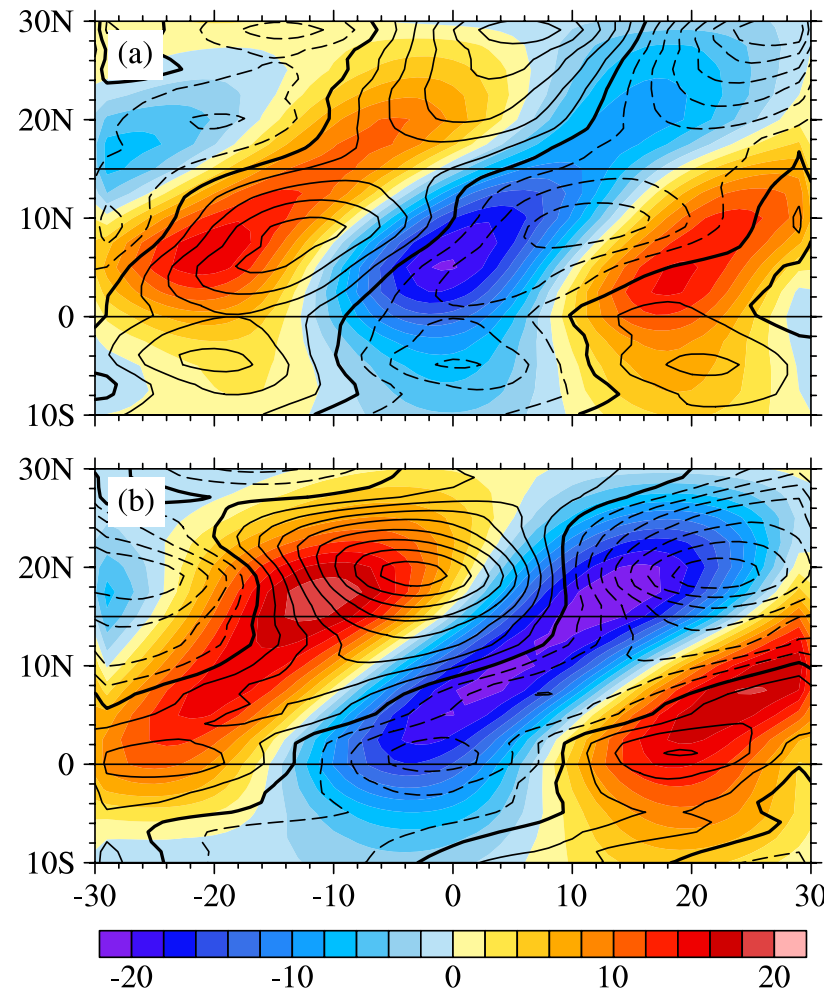

Fig. 13 As in Fig. 9, but for ISO OLR (colors, $\mathrm{W} \mathrm{m}^{-2}$ ) and SST anomalies (contours, negative is dashed, the interval is $0.05 \mathrm{~K}$, and the zero contours are bolded) evolutions of ISO OLR and SST anomalies composited in El Niño and La Niña decaying summer. ISO SST anomalies show prominent NP over the western Pacific in both El Niño and La Niña decaying summers, and positive SST anomalies are leading the convection activity. ISO SST anomalies are stronger near the equator and north of $25^{\circ} \mathrm{N}$ in El Niño decaying summer (Fig. 13a), but they are much stronger over $15^{\circ}-25^{\circ} \mathrm{N}$ in La Niña decaying summer (Fig. 13b). The stronger ISO SST anomalies over $15^{\circ}-25^{\circ} \mathrm{N}$ in La Niña decaying summer may account for the stronger NP there through air-sea interaction.

During the suppressed phases of BSISO convection, the ocean receives more solar radiation, which could promote the increase of SST. Consequently, the increased SST could moisten and destabilize the atmosphere by releasing latent and sensible heat fluxes (Fu and Wang 2004; Ajayamohan et al. 2008; Wang et al. 2018b). Figure 14 shows the composite ISO SST anomalies, OLR, and surface heat flux components averaged over $15^{\circ}-25^{\circ} \mathrm{N}, 120^{\circ}-140^{\circ} \mathrm{E}$ in ENSO decaying summer. In El Niño decaying summer (Fig. 14a), temporal evolutions of OLR, downward net heat flux (Qnet), downward shortwave radiative flux (SWF) and upward longwave radiative flux (LWF) are almost in-phase and lead the variation of SST, which indicate that more shortwave radiative flux can reach into sea surface during the suppressed phases of convection and promote the increases of SST. Positive SST anomalies lead the upward sensible heat (SHF) and latent heat (LHF) fluxes about 10 days. Then the convection reaches its peak about at day 15 , lagging the upward sensible and latent heat fluxes. In La Niña decaying summer

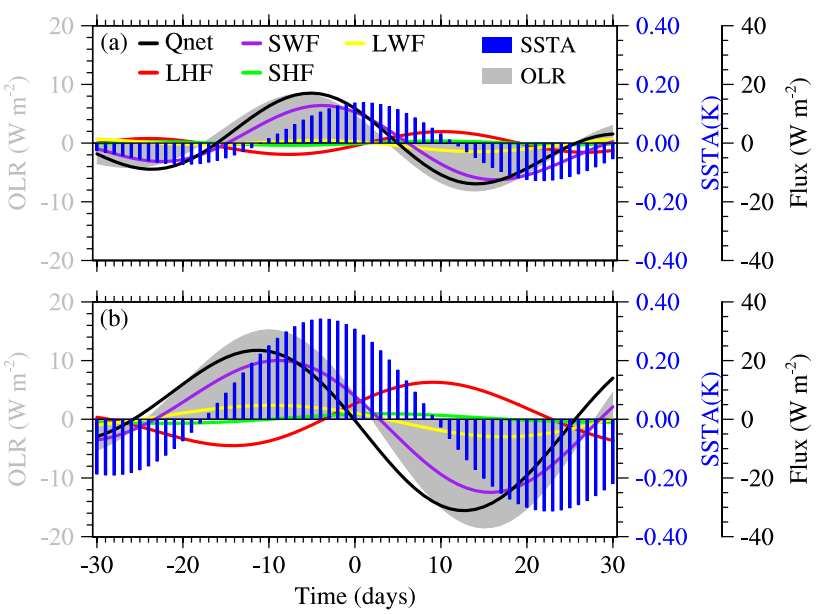

Fig. 14 Composite ISO (grey color) OLR $\left(\mathrm{W} \mathrm{m}^{-2}\right)$, (blue bars) SST anomalies (SSTA, K), (black lines) downward net heat flux (Qnet), (purple lines) downward shortwave radiative flux (SWF), (yellow lines) upward longwave radiative flux (LWF), (red lines) latent heat flux (LHF), and (green lines) upward sensible heat flux (SHF) averaged over $15^{\circ}-25^{\circ} \mathrm{N}, 120^{\circ}-140^{\circ} \mathrm{E}$ in a El Niño and b La Niña decaying summer 
(Fig. 14b), these lead-lag relationships also exist, but the intensity of SST, OLR and surface heat flux components anomalies is much stronger, which implies that the air-sea interaction in La Niña decaying summer may be stronger. The leading-lagging relationship among SST anomalies, surface heat fluxes, and OLR confirms the effects of air-sea interaction on the NP of BSISO (Chou and Hsueh 2010; Wang et al. 2018b). Thus, the stronger air-sea interaction over $15^{\circ}-25^{\circ} \mathrm{N}$ in La Niña decaying summer could also promote the stronger NP by enhancing evaporation and sensible heat flux.

\section{Conclusions and discussions}

In boreal summer, vigorous BSISO activity and its interannual variations are observed over the western Pacific. The influences of ENSO on the activity of BSISO over the western Pacific and its NP in decaying summer are explored. The intensity of BSISO activity over the western Pacific is weakened (enhanced) in El Niño (La Niña) decaying summer. BSISO shows robust NP from the equator to the north of $25^{\circ} \mathrm{N}$ over the western Pacific in La Niña decaying summer, while it is rapidly weakened to the north of $15^{\circ} \mathrm{N}$ in El Niño decaying summer.

The low-frequency background flows undergo drastic changes between the El Niño and La Niña decaying summers. In El Niño decaying summer, an anomalous anticyclonic circulation in the low-level troposphere is observed over the western Pacific, which leads to the moisture divergence and weakens the convection there. In La Niña decaying summer, an anomalous cyclonic circulation is located over the western Pacific, which enhances the moisture convergence. The anomalous ascending motion and enhanced convection also occur over the western Pacific in La Niña decaying summer. Therefore, the low-frequency background flows are unfavorable (favorable) to the BSISO activity under El Niño (La Niña) condition.

The moistening to the north of the BSISO convection center is vigorous and stronger in La Niña decaying summer, which results in the stronger NP of BSISO. The stronger positive moisture tendency over $10^{\circ}-20^{\circ} \mathrm{N}$ is mainly induced by the meridional advection of moisture. Further studies showed that the meridional advection of moisture is dominated by the advection of ISO moisture induced by LFBS meridional wind. The advection of LFBS moisture caused by the ISO meridional wind also contributes to the moistening over $10^{\circ}-15^{\circ} \mathrm{N}$. Vertical advection of moisture, especially the advection of LFBS moisture by ISO ascending motion, results in the strong moistening over $20^{\circ}-25^{\circ} \mathrm{N}$. However, the stronger negative meridional advection of moisture over $20^{\circ}-25^{\circ} \mathrm{N}$ leads to drying the atmosphere in El Niño decaying summer, which counteracts some moistening effects of vertical moisture advection. Combined effects of specific humidity and winds at LFBS and ISO timescales play an essential role in the differences of moistening north of convection center between El Niño and La Niña conditions. Air-sea interaction also promotes the NP of BSISO by moistening the low-level atmosphere and destabilizing the atmosphere. ISO SST anomalies are stronger over $15^{\circ}-25^{\circ}$ $\mathrm{N}$ in La Niña decaying summer, which could promote the stronger NP by enhancing evaporation and sensible heat flux.

The moisture-convection feedback, air-sea interaction, vertical wind shear, and advection of vorticity are the mechanisms for the NP of BSISO over the western Pacific. But the moisture-convection feedback and air-sea interaction are the main two mechanisms that lead to the stronger activity and NP of BSISO in La Niña decaying summer. The moisture-convection feedback promotes the stronger $\mathrm{NP}$ all the regions, and the effects of air-sea interaction are mainly over $15^{\circ}-25^{\circ} \mathrm{N}$. The stronger easterly vertical wind shear could also contribute the stronger NP via vertical wind shear mechanism and convective momentum transport, but its effects are weak and mainly confined to the south of $20^{\circ}$ $\mathrm{N}$. Vorticity advection may be an important reason for the BSISO NP over the western Pacific, but it is not responsible for the differences in the BSISO activity during the contrasting phases of ENSO because of the northerly vertical wind shear to the north of $15^{\circ} \mathrm{N}$ is stronger in El Niño decaying summer.

SST anomalies in the Indian Ocean play an important role in the formation of the anticyclone circulation over the western Pacific in El Niño decaying summer (Xie et al. 2009), and the activity of BSISO also modified by the SST anomalies in the Indian Ocean (Ajayamohan et al. 2008). This means that the SST anomalies in the Indian Ocean could influence the BSISO activity over the western Pacific. This issue is beyond the scope of this paper and will be investigated in our future research. Taking a quick look, SST anomalies in the Indian Ocean in the summers of 1992 and 1995 differ from other El Niño decaying summers, whereas the BSISO activity and propagation in 1992 and 1995 summers do not show prominently distinct features compared with them in other summers (not shown). This finding indicated that the influence of summer SST anomalies in the Indian Ocean on BSISO over the western Pacific may not be significant, but more detailed and in-depth studies and numerical simulations are needed.

The results in this paper are based on composite analyses, which capture the main common features of BSISO in El Niño and La Niña decaying summer. BSISO activity also shows year-to-year variations in El Niño and La Niña decaying summer. There is no NP BSISO case identified in 2011 summer (a La Niña decaying summer), and there are three obvious NP BSISO cases in 2016 summer (a El Niño decaying summer). These year-to-year variations and their 
reasons may be a good topic for future research. As annotated in the introduction, the NP of BSISO has significant impacts on the weather and climate over the East Asia. This study established a relationship between the NP of BSISO and ENSO events, which could provide suggestions to the weather prediction on intraseasonal timescale.

Acknowledgements This research is supported by the National Key Research and Development Program of China (Grant No. 2018YFC1505901) and the National Nature Science Foundation of China (Grant No. 41520104008, 41475070, 41575062). The authors would like to thank three anonymous reviewers for comments that have helped to clarify and improve this paper.

Open Access This article is licensed under a Creative Commons Attribution 4.0 International License, which permits use, sharing, adaptation, distribution and reproduction in any medium or format, as long as you give appropriate credit to the original author(s) and the source, provide a link to the Creative Commons licence, and indicate if changes were made. The images or other third party material in this article are included in the article's Creative Commons licence, unless indicated otherwise in a credit line to the material. If material is not included in the article's Creative Commons licence and your intended use is not permitted by statutory regulation or exceeds the permitted use, you will need to obtain permission directly from the copyright holder. To view a copy of this licence, visit http://creativecommons.org/licenses/by/4.0/.

\section{References}

Ajayamohan RS, Rao SA, Yamagata T (2008) Influence of Indian Ocean Dipole on poleward propagation of boreal summer intraseasonal oscillations. J Climate 21:5437-5454

Bellon G, Sobel AH (2008) Instability of the axisymmetric monsoon flow and intraseasonal oscillation. J Geophys Res 113:D07108

Chen X, Li CY, Tan YK (2015) The influence of El Niño on MJO over the Equatorial Pacific. J Ocean Univ China 14:1-8

Chen X, Ling J, Li CY (2016) Evolution of Madden-Julian Oscillation in two types of El Niño. J Climate 29:1919-1934. https://doi. org/10.1175/JCLI-D-15-0486.1

Chen L, Sun DZ, Wang L, Li T (2019) A further study on the simulation of cloud-radiative feedbacks in the ENSO cycle in the tropical Pacific with a focus on the asymmetry. Asia Pac J Atmos Sci 55:303-316. https://doi.org/10.1007/s13143-018-0064-5

Chou C, Hsueh YC (2010) Mechanisms of northward-propagating intraseasonal oscillation-a comparison between the Indian Ocean and the western North Pacific. J Climate 23:6624-6640

Dee DP, Uppala MS, Simmons AJ et al (2011) The ERA-Interim reanalysis: configuration and performance of the data assimilation system. Q J R Meteorol Soc 137:553-597. https://doi.org/10.1002/ qj. 828

DeMott CA, Stan C, Randall DA (2013) Northward propagation mechanisms of the boreal summer intraseasonal oscillation in the ERAInterim and SP-CCSM. J Climate 26:1973-1992

DeMott CA, Klingaman NP, Woolnough SJ (2015) Atmosphere-ocean coupled processes in the Madden-Julian Oscillation. Rev Geophys 53:1099-1154. https://doi.org/10.1002/2014RG000478

Drbohlav HKL, Wang B (2005) Mechanism of the northward-propagating intraseasonal oscillation: insights from a zonally symmetric model. J Climate 18:952-975

Duchon CE (1979) Lanczos filtering in one and two dimensions. J Appl Meteorol 18:1016-1022
Fu X, Wang B (2004) Differences of boreal summer intraseasonal oscillations in an atmosphere-ocean coupled model and atmosphereonly model. J Climate 17:1263-1271

Fu X, Wang B, Li T, McCreary JP (2003) Coupling between northward-propagating, intraseasonal oscillations and sea surface temperature in the Indian Ocean. J Atmos Sci 60:1733-1753

Gao Y, Klingaman NP, DeMott CA, Hsu PC (2019) Diagnosing ocean feedbacks to the BSISO: SST-modulated surface fluxes and the moist static energy budget. J Geophys Res Atmos 124:146-170. https://doi.org/10.1029/2018JD029303

Hendon HH, Wheeler MC, Zhang CD (2007) Seasonal dependence of the MJO-ENSO relationship. J Climate 20:531-543

Huang B, Thorne PW, Banzon VF et al (2017) Extended reconstructed sea surface temperature, version 5 (ERSSTv5): upgrades, validations, and intercomparisons. J Climate 30:8179-8205. https://doi. org/10.1175/JCLI-D-16-0836.1

Hsu P, Xiao T (2017) Differences in the initiation and development of the Madden-Julian Oscillation over the Indian Ocean associated with two types of El Niño. J Climate 30:1397-1415. https ://doi.org/10.1175/JCLI-D-16-0336.1

Hsu HH, Weng CH, Wu CH (2004) Contrasting Characteristics between the northward and eastward propagation of the intraseasonal oscillation during the boreal summer. J Climate 17:727-743

Jiang X, Li T, Wang B (2004) Structures and mechanisms of the northward propagating boreal summer intraseasonal oscillation. J Climate 17:1022-1039

Jiang X, Adames ÁF, Zhao M, Waliser D, Maloney E (2018) A unified moisture mode framework for seasonality of the Madden-Julian Oscillation. J Climate 31:4215-4224. https://doi. org/10.1175/JCLI-D-17-0671.1

Kang IS, Kim D, Kug JS (2010) Mechanism for northward propagation of boreal summer intraseasonal oscillation: convective momentum transport. Geophys Res Lett 37:L24804

Karmakar N, Krishnamurti TN (2019) Characteristics of northward propagating intraseasonal oscillation in the Indian summer monsoon. Climate Dyn 52:1903-1916. https://doi.org/10.1007/ s00382-018-4268-2

Katsumata M, Yamada H, Kubota H, Moteki Q, Shirooka R (2013) Observed evolution of northward-propagating intraseasonal variation over the western Pacific: a case study in boreal early summer. Mon Weather Rev 141:690-706. https://doi.org/10.1175/ MWR-D-12-00011.1

Kemball-Cook S, Wang B (2001) Equatorial waves and air-sea interaction in the boreal summer intraseasonal oscillation. J Climate 14:2923-2942

Lee JY, Wang B, Wheeler MC, Fu X, Waliser DE, Kang IS (2013) Real-time multivariate indices for the boreal summer intraseasonal oscillation over the Asian summer monsoon region. Climate Dyn 40:493-509. https://doi.org/10.1007/s0038 2-012-1544-4

Li JY, Mao JY (2019) Factors controlling the interannual variation of 30-60-day boreal summer intraseasonal oscillation over the Asian summer monsoon region. Climate Dyn 52:1651-1672. https://doi. org/10.1007/s00382-018-4216-1

Liebmann B, Smith CA (1996) Description of a complete (interpolated) outgoing longwave radiation dataset. Bull Am Meteorol Soc 77:1275-1277

Lin A, Li T (2008) Energy spectrum characteristics of boreal summer intraseasonal oscillations: climatology and variations during the ENSO developing and decaying phases. J Climate 21:6304-6320. https://doi.org/10.1175/2008JCLI2331.1

Liu F, Wang B (2014) A Mechanism for explaining the maximum intraseasonal oscillation center over the western North Pacific. J Climate 27:958-968. https://doi.org/10.1175/JCLI-D-12-00797.1 
Liu F, Wang B, Kang I (2015) Roles of barotropic convective momentum transport in the intraseasonal oscillation. J Climate 28:49084920. https://doi.org/10.1175/JCLI-D-14-00575.1

Liu F, Li T, Wang H, Deng L, Zhang YW (2016) Modulation of boreal summer intraseasonal oscillations over the western North Pacific by ENSO. J Climate 29:7189-7201

Liu F, Zhao J, Fu X, Huang G (2018) The role of shallow convection in promoting the northward propagation of boreal summer intraseasonal oscillation. Theor Appl Climatol 131:1387-1395

Madden RA, Julian PR (1971) Detection of a 40-50-day oscillation in the zonal wind in the tropical Pacific. J Atmos Sci 28:702-708

Madden RA, Julian PR (1972) Description of global scale circulation cells in the Tropics with a 40-50-day period. J Atmos Sci 29:1109-1123

Reynolds RW, Smith TM, Liu CY, Chelton DB, Casey KS, Schlax MG (2007) Daily high-resolution-blended analyses for sea surface temperature. J Climate 20:5473-5496

Teng H, Wang B (2003) Interannual variations of the boreal summer intraseasonal oscillation in the Asian-Pacific region. J Climate $16: 3572-3584$

Wang B, Xie X (1996) Low-frequency equatorial waves in vertically sheared zonal flow. Part I: stable waves. J Atmos Sci 53:449-467

Wang B, Wu R, Fu X (2000) Pacific-East Asian teleconnection: how does ENSO affect East Asian climate? J Climate 13:1517-1536

Wang WQ, Chen MY, Kumar A (2009) Impacts of ocean surface on the northward propagation of the boreal summer intraseasonal oscillation in the NCEP Climate forecast system. J Climate 22:6561-6576

Wang H, Liu F, Wang B, Li T (2018a) Effects of intraseasonal oscillation on South China Sea summer monsoon onset. Climate Dyn 51:2543-2558. https://doi.org/10.1007/s00382-017-4027-9

Wang TY, Yang XQ, Fang JB, Sun XG, Ren XJ (2018b) Role of air-sea interaction in the 30-60-day boreal summer intraseasonal oscillation over the western North Pacific. J Climate 31:1653-1680

Wang L, Li T, Chen L et al (2018c) Modulation of the MJO intensity over the equatorial western Pacific by two types of El Niño. Climate Dyn 51:687-700. https://doi.org/10.1007/s0038 2-017-3949-6

Wu RG, Song L (2018) Spatiotemporal change of intraseasonal oscillation intensity over the tropical Indo-Pacific Ocean associated with
El Niño and La Niña events. Climate Dyn 50:1221-1242. https:// doi.org/10.1007/s00382-017-3675-0

Wu B, Li T, Zhou T (2010) Asymmetry of atmospheric circulation anomalies over the western North Pacific between El Niño and La Niña. J Climate 23:4807-4822. https://doi.org/10.1175/2010J CLI3222.1

Xie P, Arkin PA (1997) Global precipitation: A 17-year monthly analysis based on gauge observations, satellite estimates, and numerical model outputs. Bull Am Meteorol Soc 78:2539-2558

Xie X, Wang B (1996) Low-frequency equatorial waves in vertically sheared zonal flow. Part II: unstable waves. J Atmos Sci 53:3589-3605

Xie S, Hu K, Hafner J, Tokinaga H, Du Y, Huang G, Sampe T (2009) Indian Ocean capacitor effect on Indo-western Pacific climate during the summer following El Niño. J Climate 22:730-747. https:// doi.org/10.1175/2008JCLI2544.1

Yang YM, Wang B, Lee JY (2019) Mechanisms of northward propagation of boreal summer intraseasonal oscillation revealed by climate model experiments. Geophys Res Lett 46:3417-3425. https ://doi.org/10.1029/2018GL081612

Yu L, Weller RA (2007) Objectively analyzed air-sea heat fluxes for the global ice-free oceans (1981-2005). Bull Am Meteorol Soc 88:527-539. https://doi.org/10.1175/BAMS-88-4-527

Zhang CD (2013) Madden-Julian Oscillation: bridging weather and climate. Bull Am Meteorol Soc 94:1849-1870

Zhang CD, Ling J (2017) Barrier effect of the Indo-Pacific Maritime Continent on the MJO: perspectives from tracking MJO precipitation. J Climate 30:3439-3459

Zheng B, Huang YY (2019) Mechanisms of northward-propagating intraseasonal oscillation over the South China Sea during the premonsoon period. J Climate 32:3297-3311

Zhou L, Murtugudde R (2014) Impact of northward-propagating intraseasonal variability on the onset of Indian summer monsoon. J Climate 27:126-139

Publisher's Note Springer Nature remains neutral with regard to jurisdictional claims in published maps and institutional affiliations. 